\title{
Dakwah Patterns and Communication of Student Character Program at Al-Fityan Kubu Raya
}

\author{
Muh. Gitosaroso ${ }^{1 *} \&$ Harjani Hefni ${ }^{2}$ \\ ${ }^{12}$ Insitut Agama Islam Negeri (IAIN) Pontianak, Indonesia
}

*gitosaroso80@gmail.com

\begin{abstract}
This study aims to determine the pattern of da'wah and communication used by the Al-Fityan Kubu Raya Foundation in forming students' Akblaq al-Karimah in established character education programs, both in schools and in dormitories. The research was conducted using a descriptive approach obtained through interviews, observation, and documentation. Based on the data obtained, the da'wah pattern carried out by the Al-Fityan Foundation was bi allisan (warnings, calls, appeals, and words), bi al-hal (through examples of behavior directly given by educators/mentors), and bi al-arkan (through the rules). Meanwhile, the communication pattern is face-to-face through various learning models, namely: Circular, straight back, and Letter $U$ in the character education mentoring program.
\end{abstract}

Keywords : mentoring; character building; da'wah; communication.

\begin{abstract}
ABSTRAK
Penelitian ini bertujuan untuk mengetahui pola dakwah dan komunikasi yang digunakan oleh Yayasan Al-Fityan Kubu Raya dalam membentuk Akblakul Karimah siswa pada program pendidikan karakter ditetapkan, baik di Sekolah maupun di Asrama. Penelitian dilakukan dengan menggunakan pendekatan deskriptif yang diperoleh melalui wawancara, observasi dan dokumentasi. Berdasarkan data yang diperoleh, ditemukan bahwa pola dakwah yang dilakukan oleh Yayasan Al-Fityan adalah dakwah bil-lisan (peringatan, seruan, himbauan, dan perkataan), bil-hal (melalui contoh-contoh perilaku yang langsung diberikan oleh pendidik/mentor), dan bil-arkan (melalui aturan-aturan). Sedangkan pola komunikasi yang dilakukan adalah dengan cara face to face melaui ragam bentuk model pembelajaran, yaitu: Melingkar, Berbanjar, dan Letter U dalam program mentoring pendidikan karakter.
\end{abstract}

Kata Kunci: mentoring; karakter; dakwah; komunikasi.

Received: Oktober 2021. Accepted: November 2021. Published: Desember 2021. 301 


\section{INTRODUCTION}

Character building is the core value of every educational institution (Subianto, 2013). It is including Islamic educational institutions. Therefore, Islamic Educational Institutions should have activities that can direct students to have good characters. For this reason, academic institutions can use the Prophet (Muhammad P.B.U.H) as a role model and a reflection of life (Ritonga, 2013).

Efforts to educate the character of students in Islamic educational institutions are included in da'wah activities because they call and invite someone to goodness that leads to closeness to the way of Allah SWT. It is in line with the command of Allah SWT, which is affirmed in the QS. An-Nahl [16] verse 125.

Communication also has an essential role in realizing the success of da'wah (Sakdiah, 2017). Communication plays a role in conveying the message of da'wah so that it can be appropriately obtained. Good communication will give a good understanding, and vice versa; poor communication will misunderstand the communicant due to the wrong message conveyed (Fatimah, Arifin, and Sumpena, 2019).

Based on the results of observations of the Al-Fityan Kubu Raya Foundation, it is known that the school is religion-based. This school carries out the teaching and learning process as usual, like schools in general (Rahmayani, 2020). However, the Al-Fityan Foundation requires all students to live in dormitories and participate in all existing programs.

In this school, everyone will feel a religious atmosphere. Some religious phenomena can be seen clearly from the interaction of students with teachers. Students and teachers are located without distance, thus fostering a sense of kinship and a close relationship without demeaning and respecting them. All students wear the hijab, and the classrooms are separate for boys and girls. In addition, each student always politely greets each other, so it feels like being in an Islamic boarding school. Every morning when students enter the school, there will be a teacher guarding the front gate, and all students kiss the teacher's hand. Students show good morals when in the classroom and also outside the school. Before the lesson begins, students are required to read the Koran for 30 minutes. The mosque is always packed at the time of prayer. Some students also use their free time at the mosque to memorize the Qur'an.

Positive activities like this are enjoyable to study and present the 
results here. What is the pattern of da'wah and communication of the AlFityan Foundation? How are the da'wah and communication patterns used by the Al-Fityan Kubu Raya Foundation to shape the students' character?

This research is located at the Al-Fityan Kubu Raya Foundation, Jl. Raya Sungai Kakap, Pal 7, Pal 9 Village, Sungai Kakap District, Kubu Raya Regency, West Kalimantan Province. This type of research uses a qualitative approach and uses a descriptive method. Qualitative research is a research procedure that produces descriptive data in written or spoken words from people and observable behavior (Moleong, 2007). This study seeks to determine the pattern of da'wah and communication in character education programs in shaping the students' morality at the Al-Fityan Kubu Raya Foundation by understanding the da'wah and communication patterns in school dormitories. The descriptive approach is a research work mechanism that relies on descriptive descriptions of words, or sentences, which are carefully and systematically compiled from collecting data to interpreting and reporting results (Ibrahim, 2015).

Thus, in this study, the data and conclusions produced are an accurate picture of the pattern of da'wah and communication of moral development at the Al-Fityan Kubu Raya Foundation. Meanwhile, to describe the problem under study, a research design is needed from several data collection times, namely conducting observations and interviewing the problem according to the focus under study.

\section{RESULT AND DISCUSSION}

\section{Al-Fityan Islamic Education Institute}

Al-Fityan is an Islamic educational institution committed to educating the nation's children to become Islamic, pious, intelligent, creative, independent, and with character. As an Islamic educational institution, AlFityan has spread across several regions of Indonesia, such as Aceh, Medan, Tangerang, Gowa, Bogor, and Kubu Raya. Al-Fityan implements a character education program as a learning curriculum. Al-Fityan Foundation also has excellent programs, such as Tahfidz al-Quran, Science and Language, Islamic Character Building, and Mentoring.

The Al-Fityan Foundation is domiciled at the head office in Bekasi, West Java, and was established indefinitely. This foundation was founded by Kyai Muhammad Nazir Zain, Imran Rosadi, Nuryasin bin Suparmin, and Nizamuddin. Deed of minute number 1 dated November 1, 2004, drawn up before Notary Musa Muarta, Bachelor of Law, notary domiciled 
in Jakarta.

The Kubu Raya branch foundation is the 5th branch of the six existing units, including Al-Fityan Schooll Tangerang, Al-Fityan Schooll Aceh, Al-Fityan Schooll Medan, Al-Fityan Schooll Gowa, Al-Fityan Schooll Kubu Raya, and Al-Fityan School Bogor. Al-Fityan Kubu Raya Foundation began organizing educational activities on July 17, 2013, which consisted of 4 levels of education and two categories, namely: Islamic Integrated Kindergarten (TKIT), Islamic Integrated Elementary School (SDIT), Islamic Integrated Secondary School (SMPIT), Islamic Integrated High School (SMAIT). Furthermore, the Al-Fityan Foundation, located in Kubu Raya Regency, is known by the public as Al-Fityan Schooll Kubu Raya (Rahmayani, 2020).

The vision of the Al-Fityan Kubu Raya Foundation is to become a preeminent and leading educational institution in teaching, education, and management throughout Indonesia. Meanwhile, its missions are: 1) Organizing integral education oriented towards Islamic values and noble character. 2) Improving the quality of educational facilities and infrastructure. 3) Building partnerships with government, community, related institutions, and parents. 4)

They are increasing the competition for educators and education according to the standards of the Integrated Islamic School (SIT). 5) Carry out education administration according to national education standards and SIT typical of Al-Fityan Kubu Raya. 6) Implement KBM to develop personal talents who are pious, intelligent, creative, and independent and have a leadership spirit who cares about the environment and others. 7) Prepare students who have advantages in the fields of the Qur'an, foreign languages, and science. 8) Prepare students who have contemporary knowledge and master technology and compete at national and international levels. 9) Carry out financial administration under the applicable Statement of Financial Accounting Standards (PSAK).

\section{Al-Fityan Karakter Character Education Program}

The educational program implemented by the Al-Fityan Kubu Raya Foundation includes two places, namely: 1) Programs that exist in the school environment as a means to educate students to have good character; and 2) Programs that are specific to the dormitory environment. The school will coordinate with the dormitory regarding student development. For example, if it is known that there are students who do not do 
homework (PR), then the teacher concerned will report to the homeroom teacher, and this will be followed up directly by the teacher; hostel party. Vice versa, the dormitory will coordinate with the school whether students have homework or not so that when they are in the hostel, they can be directed and receive guidance.

Related parties, such as Musyrif Tarbawi, are the people who play a role in receiving the educational curriculum in the student characterbuilding program from the center, namely in Jakarta. As to who gets the curriculum, the head of the dormitory is responsible for the dormitory programs. Then from the school, the person in charge (PJ) of the student character education program, namely the Mentor, has a significant role in the moral formation program in the school.

The following is a character education program in shaping students' morals at the Al-Fityan Kubu Raya Foundation:

Firstly, Character education program in schools

The student character education program implemented in schools is mentoring. It is of more significant concern because this activity is mandatory. The Al-Fityan Foundation has also determined curriculum materials that must be delivered by mentors or mentors for mentoring activities, with the outline of the material being faith, worship, and morals. Pak Heru Purwanto, as the person in charge of male mentoring as well as the principal of a junior high school at the Al-Fityan Foundation:

"Because this mentoring is part of the curriculum. Mentoring activity is more accessible to students because they are discussed in smaller groups. We include the material in 3 achievements: faith, then worship, and morals. When someone becomes an $\mathrm{MC}$ in the mentoring activity, the others have to be quiet and listen; when someone tausiah, the others have to listen seriously. It is the morality towards the Qur'an, respecting mentors and respecting each other with fellow friends. So that's a basic form of character that grows. Then we enter materials like that where it is hoped that what is conveyed by the mentor that students do not understand can be directly asked. So the discussion is more fluid than a large study. The debate is complicated and if there are personal things to be conveyed instead not delivered" (Interview with Mr. Heru Purwanto, 57 years old, at SMAIT Al-Fityan, 20 July 2019).

Mentoring activities are carried out every Friday from 07.00 to 08.30 in the morning. The forms of patterns used during mentoring activities 
include:

Circle Pattern.

The circle pattern is one of the patterns used in da'wah activities during mentoring activities. In essence, this mentoring is the same as halaqah activities, or in Indonesian, it is a circle. In more detail, the circle pattern has been explained by one of the teachers at SMA IT Al-Fityan, namely Mr. Muhammad Ikhwan, who is a teacher of Islamic Religious Education in grades X, XI, XII as follows:

"Indeed, if we know mentoring, it will be known as halaqah, where halaqah itself is a circle. If we look at it with other terms, there is something called liqo', which means meeting. So actually, we do not provide a specific pattern but will indeed refer to the initial understanding of meeting, learning, and coaching. So, the mentoring activity may be circular and may sit in rows, and some even use the classroom as a place for mentoring, so it does not have to be in the field. Therefore, it is the policy of their respective mentors. But if it's a circle, then this mentor has a friendly impression with students to instill Islamic values more freely without any distance. The cultivation of morals is where students mingle with us, see how we do activities, joke and become their friends but remain polite and respectful to us as teachers and mentors" (Interview, Muhammad Ikhwan, 30, PAI teacher at SMA IT Al-Fityan, 25 July 2021).

So from the explanation above, it can be understood that mentoring is very familiar with the term halaqah, which means circle. The da'wah pattern in the form of a circle is the most frequently used. The reason why this circle pattern is often used is that mentors can mingle with students so that there is no distance or shyness towards mentors, as expressed by Pak Eko Prasetio as deputy head of student affairs:

"In essence, circular or straight lengthwise, both face to face. I think both are good. Why? Because they can interact with each other face to face, face to face. My favorite is circular. Because of this circular position, they can see left, right, front and side, and when from moral cultivation, they can respect their friends when they talk. Then in this circular position, they will pay close attention. Meanwhile, if it is long, usually the closest one is in front of it" (Interview with Mr. Eko Prasetio, 34, Deputy Principal for Student Affairs at SMAIT AlFityan, 26 July 2019).

The same thing was conveyed by one of the students, namely Arsha 
Iskandar Kamal class XI:

"Mentoring has a pattern; usually, it's in the shape of an O or a circle. Usually use this pattern and sometimes also use other patterns to alternate, change the atmosphere, so you don't get bored. But the most often used is a circular pattern" (Interview with Arsha Iskandar Kamal, 16, student of SMAIT Al-Fityan, 30 July 2019).

The explanation above provides information that one of the da'wah patterns used in mentoring activities at the Al-Fityan Foundation is a circle in which each class will be divided according to the Force. The explanation above also provides information that there is a more interactive interaction between students and the mentor as a mentor in the da'wah pattern in mentoring activities.

\section{Figure 1.2}

Circle Pattern on Mentoring Activities

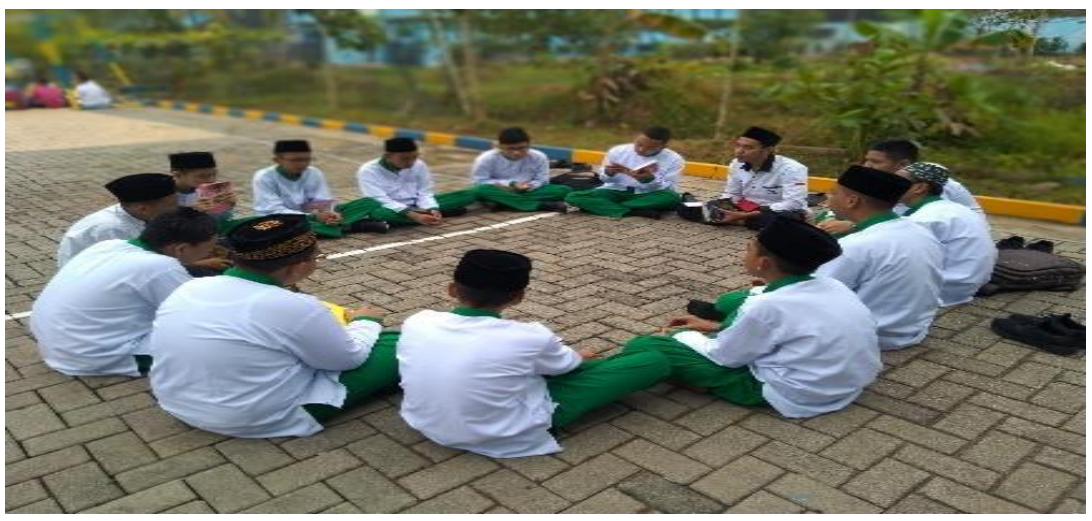

Source: Research Documentation before covid-19.

The results of observations made by researchers in February and March show that it is true that the pattern used in mentoring activities at the Al-Fityan Foundation is a circle. Then the researcher strengthened it with photos of mentoring activities with a circle pattern. With the results of observations, interviews, and documentation, the research results show that.

Row Pattern (Berbanjar)

In addition to the circle pattern used when carrying out mentoring activities, it turns out that the Al-Fityan Foundation also uses a row pattern. The berbanjar pattern is a pattern that is quite rarely used when delivering material during mentoring but will be very often used when carrying out a 
rote deposit or rote muroja'ah. Implementing the line-up pattern is a form of a line that makes students make two rows extending backward with an equal number of lengths, then in front, there will be a mentor who will provide material or instructions. Not only will they line up backward, but when they start mentoring and enter the memorization or muraja' $a b$ deposit session, each line will face each other so that everyone will have one partner to correct each other. It is as the results of observations made by researchers but will be further strengthened by the results of interviews with one of the students in class XII named Alvayed:

"Usually what is used is circle and Berbanjar, and I prefer Berbanjar, because when we are reciting the Koran, the friend in front of us can help improve our reading" (Interview with Alvayed, 17, student of SMA IT Al-Fityan, 6 August 2019).

There were also other students who said that the mentoring activities at the Al-Fityan Foundation used a line-up pattern such as the disclosure of Muh Imam for class XII students:

"Just like the friends earlier, some are circular, some are elongated but on average circular. Usually, when there are new students, all of them gather at the mosque. Before there is a mentor, they immediately make a circle" (Interview with Muh. Imam, 17 years old, Al-Fityan IT High School student, 6 August 2019).

After the data is in the form of interviews, the researcher will strengthen it with data in the form of documentation that will show the pattern of da'wah in the form of a band used by the Al-Fityan Kubu Raya Foundation in mentoring activities. 
Figure 1.3

Learning Patterns in Mentoring Activities

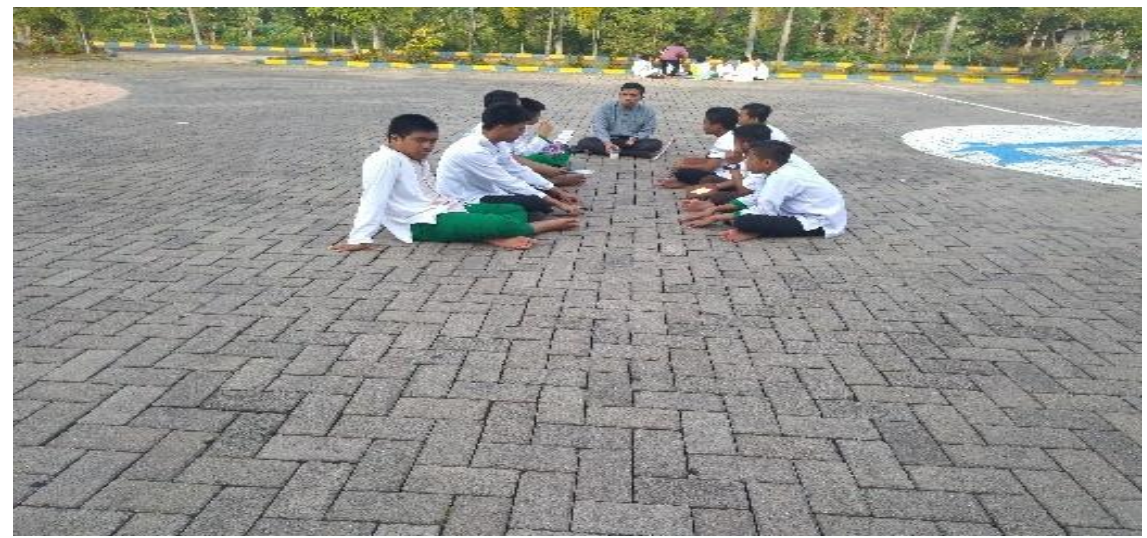

Source: Research Documentation before covid-19.

The photo further strengthens the results of observations made by researchers at the beginning of the study and supports the results of interviews.

'U' Shaped Pattern

After describing the two existing patterns, namely the circle pattern and the row pattern, the researcher will explain the following pattern, namely the 'U' shaped pattern used by the Al-Fityan Kubu Raya Foundation in mentoring activities. The way is in the shape of the letter ' $U$ '; in this pattern, students will form the letter ' $U$ ' while the mentor is on the top side. With a practice like this, the mentor will be the main focus when delivering mentoring material so that the student's focus will be sharper. However, it is scarce for mentors to use the ' $\mathrm{U}$ ' shape pattern, but several mentoring groups use this pattern. This statement is explained in more detail by Nizar Iskandar Kamal, who is a class XI student:

"It's rare to use the 'U' shape. It's been used but rarely, and I've also seen other mentoring groups use it. Usually used for students don't get bored" (Interview with Nizar Iskandar Kamal, 16, student of IT Al-Fityan High School, 6 August 2019).

And it has also been explained by a class XII student, Muhammad Refly Agustriangga:

"There are also other shapes, they are usually like squares, but oval, more like the letter' U'. So later the students make a semicircle. Still, 
it is oval. Then the mentor is in the middle" (Interview with Muhammad Refly Agustriangga, 17, Al-Fityan IT High School Student, 6 August 2019).

The same thing was also explained by a class XI student named Ibnu Siddiq, who also felt and saw the 'U' shaped pattern:

"I've also used an oval shape but rarely. So, usually when you use a shape like a letter U' because the room is narrow" (Interview with Ibnu Siddiq, 16, IT Al-Fityan High School Student, 6 August 2019).

The interview results above are a form of acknowledgment that gives us a view that there is indeed a ' $U$ '-shaped pattern used in mentoring activities at the Al-Fityan Kubu Raya Foundation. Although rarely used in mentoring activities, this pattern can be a reference. If you use this pattern, the mentor can be the center of attention for students when delivering material.

After the interviews have been presented, the researcher will deliver the research results in the form of documentation as a reinforcement of the research results.

\section{Figure 1.4}

The 'U' Shaped Pattern in Mentoring Activities

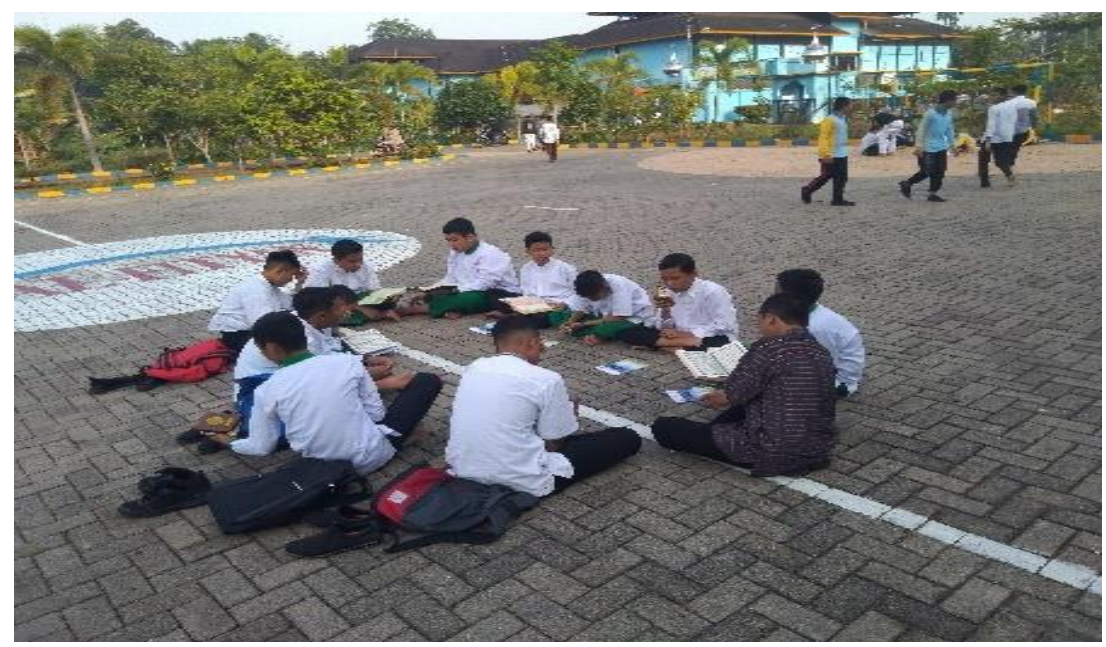

Source: Documentation before Covid-19.

Secondly, Character education program in dormitories.

In contrast to mentoring, which is a da'wah pattern in character education programs in schools and has a curriculum and affects grades in 
schools, character education programs in dormitories are not like that but still have their values or points for students. It is as stated by Bustami as musyrif tarbawi:

"So I first explained that this tarbawi musyrif had several things to do, such as coaching and evaluating all existing educational activities or programs. For ordinary religious education programs, there are already those who take care of them, namely schools. But for tarbawi, we receive from the center, namely, Jakarta. We accept curriculum from the center, such as mentoring, lectures, studies, and learning Arabic. We received all the programs from the center, along with the materials. Ade also has material characteristics from us; for example, because it is Eid al-Adha, we provide material that is not available from the center, namely, about Eid al-Adha. It is all an assessment for students. It is known that we have two report cards, namely school report cards and report cards from the government, like schools in general" (Interview with Bustami, 37 years old, Musyrif Tarbawi SMA IT Al-Fityan, August 10, 2019).

From the explanation above, we can understand that the musyrif tarbawi received the curriculum and handed it over to the school, which would then be managed as a mentoring activity and also given to the dormitory so that the dormitory is not only a place to live for students but also a place for character education.

The dormitory has activities that must be followed by all students as a form of character education at home so that students have good personalities. As for the activities such as halaqah, independent study, learning Arabic, and memorizing. Mr. Hafif has described the details of the dormitory activities as the head of the hostel at the Al-Fityan Kubu Raya Foundation:

"The children wake up at 04.00, all of them are woken up to go to the mosque for congregational prayers, al-ma'tsurat (dhikr) in the morning, then we will halaqah the Qur'an. This halaqoh is divided into tahfidz and tahsin, namely tahfidz adding memorization and tahsin improving reading. If it is 06.00 to 07.10 , they take a bath, have breakfast, and go to school, and we leave it to the school until $3 \mathrm{pm}$. Then they prayed Asr and al-Ma'tsurat in the evening. They were followed by a free schedule, which is from 4 to $5 \mathrm{pm}$. For those who want to exercise, wash or even meet their parents, we invite them" (Interview with Hafif, 36, Head of the Al-Fityan IT High School 
Dormitory, August 22, 2019).

After the results of the interviews above, the researcher will also describe in detail the activities in the dormitory:

Halaqah al-Quran and Arabic

Students' active activities while in the dormitory starts at 17.00, namely bathing and going to the mosque to perform the evening prayer. After maghrib prayer, students will perform halaqah al-Quran and Arabic. Halaqah al-Qur'an will focus on two things, namely memorizing and improving reading, while Arabic is memorizing vocabulary and practicing speaking using Arabic. Mr. Hafif explained it as the head of the hostel, namely:

"At 5 o'clock, they return to the dormitory, take a shower, then go to the mosque and learn Arabic. Then, Halaqoh until the time of Isha. In tahsin activities, they are required to undergo it for six months. After that, you can only go to tahfidz. But some are good for 2 or 3 months, immediately move to halaqah tahfidz. To memorize, a minimum of 3 juz for three years" (Interview with Hafif, 36, Head of the IT Al-Fityan High School Dormitory, August 22, 2019).

The halaqah al-Qur'an system is in the form of tahfidz, so students are instructed to memorize the Qur'an and pay it to the halaqah supervisor if the reading when the rote is correct, it will be left, but if it is wrong, it will be corrected. In contrast to tahsin, there is an interaction that is not monotonous, such as when the supervisor teaches how to read the Qur'an surah by surah. It is as explained by Mr. Mursalin as one of the musyrif as well as halaqah mentors:

"The difference between tahfiz and tahsin. For tahfiz, we listen. For example, if the reading is correct, that's it; we let it go, we need to give directions to memorize the next one. But if the reading is wrong, we will correct the reading. So that's all about it. If tahsin is different, we usually ask them to read Iqro or the Qur'an, and later we will correct the wrong letters by giving examples. It isn't easy to correct reading, such as teaching them to read, while tahfiz only memorized it. For Arabic, as usual, someone speaks, someone listens" (Interview with Mursalin, 32, Musyrif SMA IT Al-Fityan, August 22, 2019).

As for the Arabic language, the supervisor or mentor will speak in Arabic, and the students will listen, and vice versa. The students will be asked to speak, and the supervisor will listen. After that, there was also a discussion session using Arabic, for example, asking how things were, 
asking about activities at school, and other things that used Arabic.

There is no documentation on the character education program in the Dormitory because students are closed due to the covid-19 pandemic. Therefore, the researchers only present data in the form of interviews with resource persons.

Independent Learning Activities (KMB)

In addition to halaqah al-Qur'an and Arabic, independent learning activities (KBM) are carried out by students while in their respective rooms. Each room is filled with approximately 7 to 8 people. Independent learning activities are always carried out every night after the evening prayer to monitor the musyrif of the Dormitory for students to keep learning and doing the tasks assigned by the school. If there is a part of the question or task that the student does not understand, the musyrif will teach the student, but if it is in a group assignment, the student may ask for permission to do group work. Mr. Mursalin, who is one of the musyrifs of the chamber, stated this when interviewed:

"We do have an agenda; after the evening prayer, the students are told to eat, after eating there is something called KBM (Independent Learning Activities). It is the scope of the Dormitory's responsibilities, which is to remind the children of the schedule or things that they must do at night. Their work will be monitored by the musyrif of the Dormitory in each room. The form of monitoring is like a homeroom teacher, so in the Dormitory, there is a room, and the room is spacious so they can gather, do assignments or receive directions from the musyrif. Especially in the room, there are also activities such as qiyamul lail or tahajjud. Pray in the room, learn the Koran, give a speech or public speaking” (Interview with Mursalin, 32, Musyrif SMA IT Al-Fityan, August 22, 2019).

The interview results above explain that the Dormitory has a responsibility as a parent so that every student at the Al-Fityan Foundation continues to study despite having a busy activity. This program also teaches students to live disciplined and organized, and responsible.

\section{Patterns of Da'wah of Al-Fityan's Character Education Program}

According to the research focus, the data collected has been presented, namely about the pattern of da'wah and communication in the character education program at the Al-Fityan Kubu Raya Foundation. These data discussed by taking into account the sub-focus of research such as the 
pattern of da'wah and communication in shaping student morals at the AlFityan Foundation while at school and the practice of da'wah and communication in shaping student morals at the Al-Fityan Kubu Raya Foundation while in the Dormitory, following the discussion.

Da'wah activities by the Al-Fityan Kubu Raya Foundation are carried out through a character education program that includes two locations: schools and dormitories. Programs in schools are known as mentoring, while in dormitories, there are various kinds of activities such as KBM (Independent Learning Activities), halaqah al-Qur'an, and halaqah Arabic. Although with different activities and places, there are still elements of the same da'wah, here is the full description (Munir \& Ilahi, 2006).

First, $D a^{\prime} i$ (Da'wah Perpetrators) are people who carry out da'wah both orally, in writing, and actions that are carried out either individually, in groups, or through organizations/institutions. In mentoring activities, KBM, halaqah al-Qur'an, and Arabic, who act as da'i, are mentors and dormitory musyrif.

Second, Mad'u (Recipients of Da'wah) are humans who are the target of da'wah, or human recipients of da'wah, both as individuals and as groups, whether humans are Muslim or not, or in other words, humans as a whole. For people who are not yet Muslim, da'wah aims to invite them to follow Islam, while for people who are already Muslim, da'wah seeks to improve the quality of faith, Islam, and Ihsan (Azzahari, 2018). In da'wah activities in mentoring activities, students become objects of da'wah or mad'u. However, at the time in the dormitory, the status of students changes to students but still acts as mad'u.

Third, Maddah (Material) da'wah is the content of the message or material conveyed by the da'i to mad'u. In this case, the maddah of da'wah is the teachings of Islam itself. In general, da'wah material can be classified into four main problems, namely: aqidah (faith) problems, sharia problems, muamalah problems, moral problems (Mistarija, 2018). The school's curriculum material in mentoring activities discusses faith, worship, and morals. When in the dormitory, the students or students receive Arabic material and memorize the Koran.

Fourth, Wasilab (Media) Da'wah is a tool used to convey da'wah material (Islamic teachings) to mad'u. Da'wah can use various wasilah to bring the teachings of Islam to the people. Hamzah Ya'kub (in Aminudin, 2016) divides wasilah da'wah into five types: oral, written, painting, audiovisual, and moral (Aminudin, 2016). From wasilah or the media used 
by mentors and musyrifs in mentoring activities or dormitories, they often use oral or verbal communication.

Fifth, Atsar (Effect) Da'wah refers to feedback (feedback) from this da'wah process often forgotten or not much attention to the da'i. Most of them think that after the da'wah is delivered, the da'wah is finished. At the same time, atsar is very meaningful in determining the next steps of da'wah. Without analyzing the atsar of da'wah, strategic mistakes that are very detrimental to achieving the goals of da'wah may reoccur. From mentoring activities, the achievements are according to the material provided, namely faith, worship, and morals, but researchers are more focused on morals. Meanwhile, from the activities in the dormitory, it is expected that students or santri have memorized at least three chapters within three years, can speak Arabic, and become independent people in KBM (Independent Learning Activities).

Researchers will also discuss separately from the activities or programs held by the Al-Fityan Kubu Raya Foundation, following the discussion:

Firstly, Character Education Program in schools

As the researchers explained above regarding the character education program held by the Al-Fityan Foundation, which includes two scopes, namely in schools and dormitories. While in school, students will learn like schools in general, except that there is an additional program that all students must follow, and this program is included in the learning curriculum at the Al-Fityan Kubu Raya Foundation, namely mentoring. Mentoring is a character education program held by the Al-Fityan Foundation by instilling religious values in all students through communication. Da'wah activities occur, namely inviting and calling to the way of Allah. It is as explained in the Qur'an, namely:

"Call (people) to the course of your Lord with wisdom and suitable lessons and refute them in a good way. Verily, it is your Lord who knows best who has strayed from His path, and it is He who knows better those who are guided" (Surat an-Nahl [16]: 125).

Da'wah in this program is carried out in mentoring, which is part of the job description of the musyrif tarbawi. Mentoring is a da'wah activity because mentoring students will get Islamic material, including faith, worship, and morals, from a mentor. Following the notion of da'wah, da'wah is the activity of conveying messages. It contains values, norms, and religious law (Islam). The objects are individuals, groups, and communities. 
Da'wah aims to carry out spiritual teachings with full awareness so that a social system is realized harmony and peace, which ultimately brings happiness to life in this world and the hereafter (El-Ishaq, 2016).

The da'wah pattern used is mentoring, then during the mentoring implementation, there is one-way, two-way, and multi-communication communication which is part of the communication pattern. Communication that occurs during mentoring is communication between the supervisor or mentor with the students, and vice versa communication occurs between one student and another student and communication between students and their supervisors. According to D. 'Lawrence Kincaid, Hafied Cangara (2006), communication is a process in which two or more people form or exchange information with each other, which in turn will arrive at a deep mutual understanding (Hafied Cangara, 2006). From this understanding, it is clear that communication involves some people in which one person states something to another, so those involved in the touch are humans. While the pattern described by Effendy through the journal of communication science, namely the communication pattern, is a process designed to represent the reality of the interdependence of the elements covered and their continuity to facilitate systematic and logical thinking (Effendy, 2003).

Apart from that, in da'wah, some people act as da'wah interpreters who, on this occasion, are mentors or mentors from mentoring activities. In contrast, students work as people who receive da'wah or known as mad'u.

Researchers have explained that da'wah activities through mentoring include three patterns: the circle pattern, the letter ' $U$ ', and the row pattern where each pattern has a function, namely a circle for discussion, a Multicommunication pattern, a 'U' shape pattern for discussion. Delivery of material so that students focus on delivering material by the supervisor enters a one-way communication pattern. The learning line pattern when memorizing is a two-way communication pattern.

Each mentoring design turned out to be the same as the communication patterns mentioned by Effendy (2003): the one-way communication pattern is the process of delivering messages from the communicator to the communicant either using media or without media, without any feedback from the communicant, in this case, the communicant acts as a listener only. It is the same as mentoring with a ' $\mathrm{U}^{\prime}$ shape pattern where students are expected to focus on listening to their 
supervisor when delivering material. Reciprocal communication (Two-way traffic communication) is that communicators and communicants exchange functions in carrying out their functions. Communicators in the first stage become communicants and, in the following step, alternate functions. But in essence, the one who starts the conversation is the primary communicator; the main communicator has a specific purpose through the communication process, the process is dialogic, and feedback occurs directly.

Its pattern is the same as mentoring with a row. A multi-way communication pattern is the communication process that occurs in one group. Here, communicators and communicants exchange ideas in a dialogical manner. And for the last communication pattern is the same as mentoring with a circular pattern; namely, it functions when the mentor conducts discussions or questions and answers with students (Hikmat, 2011).

The implementation of mentoring activities used as a da'wah pattern can make students commendable morals, the nature of trust, al-aliyah, and al-khairu. It can be seen how when mentoring during the discussion, and students must be honest or trustworthy when delivering rote deposits and conveying their current situation, whether good or bad. When mentoring, students must also be kind to their friends and mentors or mentors who are a reflection of the nature of al-khairu so that they become a person who is liked (al-aliyah).

Secondly, Character Education Program in Dormitory

After the researcher explained the discussion about the character education program in schools, the researcher will explain the discussion about the character education program in the dormitory. Researchers have described that activities in the dormitory include KBM (self-study activities), namely students doing assignments or homework (PR) given by the school to students while in the dormitory. This activity is carried out individually; only when students are confused in doing assignments students are allowed to ask the musyrif of the dormitory in his room or ask a roommate. This type of activity refers to communication, namely communication with oneself (intrapersonal) and interpersonal communication (interpersonal).

Hafied Cangara suggests communication with oneself and interpersonal communication that communication with oneself is a communication process that occurs within the individual or, in other 
words, the method of communicating with oneself as when students are doing their homework alone. However, communication with oneself will turn into interpersonal communication when students ask a roommate's musyrif in the room or ask a roommate. Here is a communication process that takes place between two or more people face to face. Interpersonal communication can be divided into two kinds, namely dyadic communication and small group communication.

In addition to communication with oneself and interpersonal communication when carrying out independent learning activities, this communication also occurs when students carry out halaqah programs in Arabic and halaqah al-Qur'an. As researchers have explained, halaqah Arabic aims to train students to use Arabic by inviting students to memorize Arabic vocabulary and then practice it in the form of discussions or speeches using Arabic. For the halaqah al-Qur'an, students deposit their memorization while the musyrif of the dormitory muses listen and correct if an error occurs.

Based on explaining the existing programs in the dormitory, building morals, such as habituation, reward, and sanctions, is used method. According to Sa'aduddin, an example is an act that should be imitated and emulated in educational practice, and students tend to imitate their educators. Because psychologically, children like to imitate without thinking about the impact. So when a musyrif behaves well by setting an example or example in the form of getting up early to perform the dawn prayer, performing the evening prayer, and speaking good words, the students will imitate him. At the same time, the method is to educate by giving exercises to a certain norm and then getting used to repeating certain activities many times to become a part of his life, such as prayer, fasting, politeness in socializing, and the like. Students are accustomed to living disciplined and learning to be independent. The schedules that the tarbawi musyrif has arranged with all the agendas in the dormitory can be seen. The reward and sanction method also play a role in educating students while in the dormitory, namely by providing added value or appreciation for diligent students. To students who violate will also give sanctions.

\section{CONCLUSION}

In general, we can conclude that the character education program in shaping morality at the Al-Fityan Kubu Raya Foundation includes two places, namely in schools and in dormitories. The character education 
program in schools is mentoring. This activity is a pattern used as a means of da'wah, instilling an understanding of faith, worship, and morals under the mentoring curriculum at the Al-Fityan Foundation. The material will be delivered by the mentor or supervisor in the mentoring activity. The implementation of mentoring activities is carried out every week on Fridays, and mentoring activities will use patterns to facilitate communication in mentoring activities. The pattern used is a circle pattern, a row pattern, and a ' $\mathrm{U}$ ' shaped pattern. Of the three ways used by the AlFityan Kubu Raya Foundation in mentoring activities, the most frequently used is the circle pattern because the circle pattern will bring comfort between mentors and students without any distance but still maintain morals between mentors and students.

From the results of the study, three patterns are used, as the researchers have mentioned. Still, each design has its role. The position must be per its function: 1) The circle pattern is the pattern most often used during mentoring activities and has a decisive role in mentoring activities. Since, during discussion sessions on mentoring activities, between mentors and students can build intimacy. 2) The row pattern is used quite rarely, but it is more often if the mentoring activity when memorizing deposits or rote muroja'ah; and, 3) The letter ' $U$ ' pattern is the least used because, in this pattern, the mentor will be in the spotlight for students. So, the students will feel awkward and be at a distance between the mentor and the student. However, this pattern will be more appropriate if the mentor wants to convey something scientific.

In addition to character education programs in schools, there are also programs in dormitories, namely Independent Learning Activities (KBM). This program is used to train students' independence in learning and foster closeness with the dormitory musyrif in the room and roommates. Students can ask the musyrif and roommates if there are things that are not understood while studying. Besides KBM, there is also Arabic halaqah, and al-Quran halaqah, which will be guided directly by the musyrif of the dormitory with the target that students can communicate using Arabic and students can memorize a minimum of 3 juz for three years.

\section{REFERRENCES}

Aminudin. (2016). Media Dakwah. Al-Munzir, 9(2), 99-117. https://ejournal.iainkendari.ac.id/al-munzir/article/view/786. Azzahari, M. R. (2018). Strategi Unit Dakwah Jabatan Hal Ehwal Agama 
Islam Negeri Sabah ( Jheains ) Dalam Menyebarkan Dakwah Pada Non-Muslim, Idarah: Jurnal Manajemen Dan Administrasi Islam, 2(2), 43-65. https://jurnal.arraniry.ac.id/index.php/alidarah/article/view/4424.

Cangara, H. (2006). Pengantar Ilmu Komunikasi. Jakarta: Raja Grafindo Persada.

Effendy, O. U. (2003). Ilmu Komunikasi teori dan praktek. Bandung: PT Remaja Rosda Karya.

El-Ishaq, R. (2016). Pengantar Ilmu Dakwah. Jakarta: Madani Media. Fatimah, S., Arifin, I. Z., \& Sumpena, D. (2019). Komunikasi Pemberdayaan Masyarakat melalui Kegiatan Program Keluarga Harapan, Prophetica: Scientific and Research Journal of Islamic Communication and Broadcasting, 5(1), 63-80. https://doi.org/10.15575/prophetica.v5i1.1308.

Hikmat, H. (2011). Pesan-pesan Dakwah dalam Bahasa Tutur. Jurnal Ilmu Dakwah, $5(1)$, $257-270$.

http://journal.uinsgd.ac.id/index.php/jid/article/view/366

Ibrahim. (2015). Metodologi Penelitian Kualitatif. Bandung: Alfabeta.

Mistarija. (2018). Materi Dakwah dalam Al-Qur'an dan Al-hadits, Tahwir: Jurnal Pengembangan Masyarakat Islam, 1(2), 11-22. https://ejournal.uinib.ac.id/jurnal/index.php/tathwir/article/view /46/46.

Moleong, L. J. (2007). Metodologi Penelitian Kualitatif. Bandung: PT Remaja Rosdakarya.

Munir., \& Ilahi, W. (2006). Manajemen Dakwah. Jakarta: Kencana.

Rahmayani. (2020). Manajemen Sarana Prasarana Dalam Meningkatkan Produktivitas Sekolah Menengah Pertama Islam Terpadu (Smpit) AlFityan School Kubu Raya, Jurnal Pendidikan dan Pembelajaran Khatulistiwa, 9(12), 152-160. https://journal.ikippgriptk.ac.id/index.php/edukasi/article/view/1 978.

Ritonga, A. R. (2013). Keteladanan Rasulullah dalam Pendidikan Berkarakter, Jurnal Al-Hurriyah, 14(1), 1-12. DOI : 10.30983/alhurriyah.v14i1.593.

Sakdiah, H. (2017). Komunikasi Interpersonal sebagai Strategi Dakwah Rasulullah (Perspektif Psikologi), Alhadharah, 15(30), 1. https://doi.org/10.18592/alhadharah.v15i30.1219

Subianto, J. (2013). Peran Keluarga, Sekolah, Dan Masyarakat Dalam 
Dakwah Patterns and Communication of Student Character Program at Al-Fityan Kubu Raya

Pembentukan Karakter Berkualitas, Edukasia: Jurnal Penelitian Pendidikan Islam, 8(2), 331-354. https://doi.org/10.21043/edukasia.v8i2.757. 
